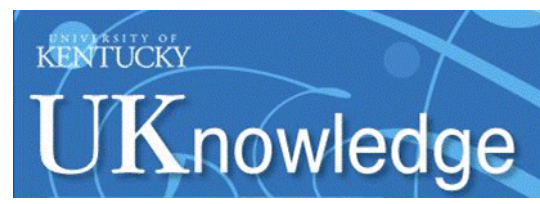

University of Kentucky

UKnowledge

\title{
Academic Libraries and Automation: A Historical Reflection on Ralph Halsted Parker
}

C. Sean Burns

University of Kentucky, sean.burns@uky.edu

Follow this and additional works at: https://uknowledge.uky.edu/slis_facpub

Part of the Library and Information Science Commons

Right click to open a feedback form in a new tab to let us know how this document benefits you.

\section{Repository Citation}

Burns, C. Sean, "Academic Libraries and Automation: A Historical Reflection on Ralph Halsted Parker" (2014). Information Science Faculty Publications. 6.

https://uknowledge.uky.edu/slis_facpub/6

This Article is brought to you for free and open access by the Information Science at UKnowledge. It has been accepted for inclusion in Information Science Faculty Publications by an authorized administrator of UKnowledge. For more information, please contact UKnowledge@lsv.uky.edu. 


\section{Academic Libraries and Automation: A Historical Reflection on Ralph Halsted Parker}

\section{Notes/Citation Information}

This article first appeared in portal: Libraries and the Academy, v. 14, no. 1 (Jan. 2014): 87-102.

Copyright @ 2013 The Johns Hopkins University Press. 


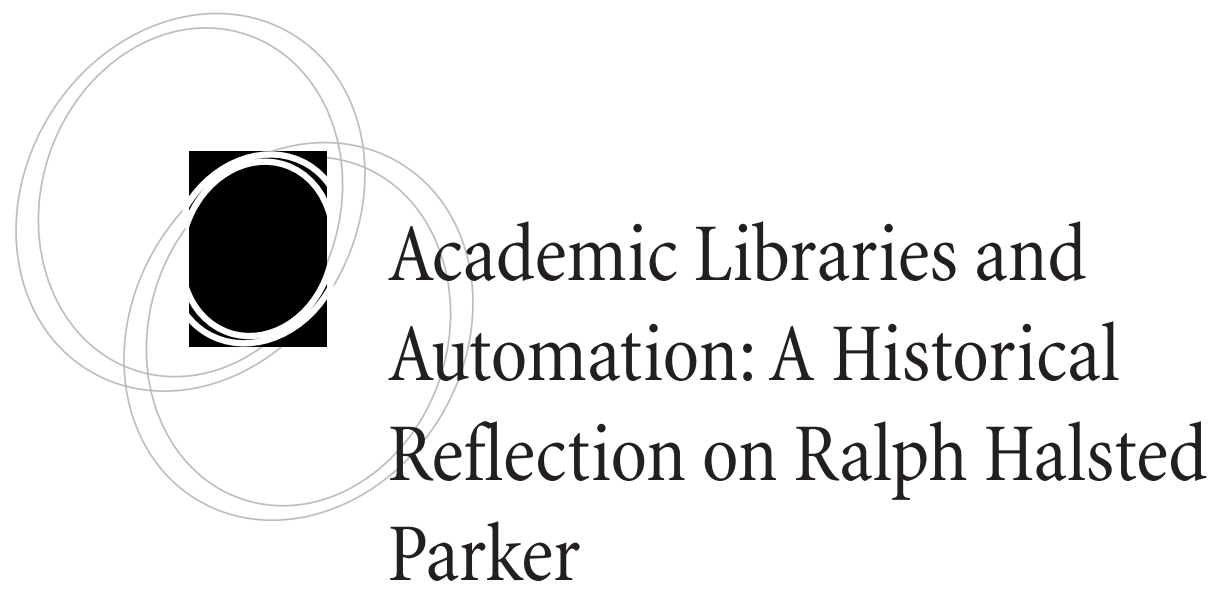

\title{
C. Sean Burns
}

\begin{abstract}
This paper provides a historical account of Ralph Halsted Parker and his work to automate libraries in the early to middle parts of the twentieth century. One of Parker's motivations to automate stemmed from a desire to professionalize academic librarianship, and this is evident in his administration as library director at the University of Missouri. Importantly, the motivation implies a simple means of judging the critical use of technology: that any substantive technology should be evaluated by how well it benefits librarians. Parker's additional contributions included consulting and coauthoring, with Frederick G. Kilgour, the report that led to the Online Computer Library Center (OCLC), the world's largest bibliographic database.
\end{abstract}

\section{Introduction}

I

$\mathrm{n}$ the late nineteenth and early twentieth centuries, the growth in the number of $\mathrm{PhDs}$ and their research output meant that the theory and praxis of librarianship needed to develop the kinds of technologies that could quickly organize the vast amount of scholarship being produced. ${ }^{1}$ These technologies eventually became important enough to the librarian's function and ingrained within the identity of the discipline that it now seems to be more common to address how technology serves librarians' communities rather than librarians themselves.

The professional cost of this development may result in the idea that librarians have one major function, and this function is to use technology to provide some service to some community outside themselves. Is this the primary purpose of technology? If not, then what other purpose can technology serve? If the answer to the former question is 
affirmative, then it seems that all future discussions about both libraries and technology should assume some kind of tension as technology, and especially information-related technology, becomes increasingly decentralized. That is, as information providers, such as open-access journals, and information pointers, such as search engines, become dominant sources of information and sources of discovery and access to information, then our evaluation of these and other tools should likely be framed as a kind of tension (or competition) between the services that librarians offer and the services that these other entities provide.

Eldred Smith noted the tension in 1990 when he described the challenge for research librarians in the "electronic era" by writing:

\begin{abstract}
Research librarians face an extremely consequential choice, certainly the most consequential in history. They can continue to function as they have in a print environment, seeking to gather and preserve copies of scholarly products as more and more of these products become electronic. They can struggle to adapt increasingly outmoded practices to new conditions, as the scholarly record which they have played such a critical role in achieving and maintaining gradually loses its integrity. Conversely, they can take advantage of the new technology in order to maintain and even improve the record's integrity. Accomplishing this will be a formidable task. It will require, more than anything else, an intense, committed, collaborative effort on the part of all research librarians. Its alternative, however, may well be dissolution of the record of scholarship as well as the research library [emphasis added]. ${ }^{2}$
\end{abstract}

By detailing the task's requirements and actions, as well as the stakes involved, Smith hints that the task concerns a service to the profession as well as to its professional identity. Smith also notes that while technology provides the set of challenges, technology can also be used to respond to those challenges. Essentially, the ability to function as a collective while taking ownership of technology is, Smith seems to think, librarians' saving grace. This joint ability, however, involves librarians acting in a certain way; specifically, it means negotiating their "link of jurisdiction."3 One way to determine how the negotiating works is by reflecting on how technology has changed and still changes librarianship, and by assessing how it advances or limits the field.

Drawing upon historical documents, this paper has two motivations. First, rather than describe the possibilities the "electronic era" has for service to the community or the (existential) challenges it creates for the profession, this study describes how the original motivation to automate the library, which was to enhance to practice of librarianship, continues to be relevant. To illustrate, this paper provides a historical account of a librarian, Ralph Halsted Parker, and his work to move librarianship into the early electronic era beginning in the 1930s. Many pioneering librarians in the twentieth century were part of this effort, and these pioneers include such luminaries as Henriette Avram and Frederick Kilgour. Parker, however, provides an important case study for at least two reasons: He was the first person to introduce machine automation into the library, ${ }^{4}$ and his continued work on the automation project for several decades resulted in important contributions. These contributions included, for example, coauthoring with Frederick Kilgour in 1965 the report that initiated the founding of the Ohio College Library Center, now the Online Computer Library Center (OCLC). ${ }^{5}$ 
Historically, Parker's contributions are interesting because his motivation to automate can be partially traced to his desire to intellectualize and professionalize the field of librarianship. In the 1936 Library Journal article where he introduced the first working example of library automation, he wrote that the eventual outcome of automation would be "a new day of no mistakes, no nervous strain, and much less manual labor for the library worker." ${ }^{6}$ While perhaps a bit optimistic, the tangible, directly observable outcomes of this and his later contributions eventually included the uses of the tools, systems, and machinery needed for automation. His intellectual contribution, based on

The eventual outcome of automation would be "a new day of no mistakes, no nervous strain, and much less manual labor for the library worker." his motivation, though, included the intent to professionalize the field. This is evident in his later annual librarian reports, ${ }^{7}$ which describe an unsatisfactory state of affairs for the librarians at the University of Missouri (MU) when he began his administration there as director of libraries in 1947, and his efforts to make the work better for the librarians. For Parker, raising the value of the profession and extending service to the community were two sides of the same coin. Automating the library was a means to raise that coin's value.

Providing an account of Parker's role in the history of library automation is a second, corollary motivation for this study. ${ }^{8}$ More broadly, the history of library automation is an important area of library and information science research because, among other reasons, of its impact on how librarians do their work today. From this perspective, two aspects from this history stand out. One, library automation transformed a completely manual library into a machine-assisted one. This change eased the

For Parker, raising the value of the profession and extending service to the community were two sides of the same coin. burden and drudgery associated with the many mundane tasks that dominated a nonautomated library. ${ }^{9}$ Perhaps arguably, it transformed the library into a more efficient, cost-effective, and potentially intellectually engaging operation. Two, although library automation started as in-house experimentations, it evolved into projects connecting libraries to national, and later international, loosely knit cooperatives. This allowed librarians a more effective means to distribute limited labor and resources and to increase access to collections. Combined, these two aspects of library automation have largely defined the shape, the processes, and the identity of librarianship today, and thus make the history of automation a fundamental area of study for library science. Parker's contribution to this effort was substantial.

\section{Scope}

The integration of libraries and automation, in the form of punched cards, begins with Ralph H. Parker in $1936 .{ }^{10}$ In this paper, I draw upon Parker's publications and the material archived at MU as a result of his tenure there. Parker's archival records at MU begin in 1947, when he joined the university as director of libraries. He held this role until 1969, 
the last two years serving as interim university librarian while he was establishing MU's library school as its first dean. The archives, which include reports, correspondence, and notes as well as two mid-1970 oral histories, provide a unique view of an active time in the library's history as well as insights into the broader history of library automation and academic libraries. The material also offers a glimpse of the obstacles and politics that come packaged with university librarianship.

I follow the account of Parker's automation efforts with a reflection on what computerization, and more generally, technology, means for librarianship. Parker's intellectual contribution, to introduce automation into the library in order to augment library practice and raise the librarian's status, ${ }^{11}$ is a valuable heuristic when considering the use of any kind of technology for library or librarians' use. I use the term heuristic purposefully, as Parker's contribution suggests a way of evaluating the use of some thing not by whether it only serves the user but by whether it jointly serves the user and the profession.

Although the scope of this study primarily spans his tenure at MU, Parker's automation work first appeared in a 1936 Library Journal article, which described a punchedcard-based library automation system that he developed and used for circulation at the University of Texas. Robert V. Williams noted in his article on the history of punched

Judith Hopkins called Parker "the father of library automation in the United States." cards in libraries that following Parker's article and "over the next 25 years, Parker would be an exceptional advocate of machine-sorted cards." ${ }^{12}$ Indeed, his influence in this area, extending beyond machine-sorted cards to systematic and integrated computer automation in general, was apparently established as early as 1973, when Judith Hopkins called Parker "the father of library automation in the United States."13

A study of Parker's papers and reports lends itself to the view that the introduction of technology was driven by a desire to raise the quality of librarians' work and work life- to make librarianship better for librarians. To frame this motivation, some understanding of academic librarianship, in Parker's context, follows.

\section{Ralph Halsted Parker: Automation at MU and Beyond}

Although present-day library literature often speaks to the extensive change our profession is undergoing, the hardship our libraries are experiencing, and the lack of status

\section{The introduction of technology was driven by a desire to raise the quality of librarians' work and work life-to make librari- anship better for librarians.} for academic librarians, current changes, hardships, and status issues pall compared with what was experienced during much of the twentieth century. At MU, for example, before Parker became director of libraries in April 1947, World War II era enrollment fell approximately 70 percent $(5,000$ students in 1938 to around 1,500 students in 1943). ${ }^{14}$ In response to this and other issues, the salaries for the librarians, of which there were five grades, ${ }^{15}$ froze at a reduced rate that lasted long after the war ended. ${ }^{16}$ In one of his first annual reports, Parker reported to university 
President Frederick Middlebush that he had sent a letter to the University of Texas, and then follow-up letters to other regional universities, to gather comparative numbers on salaries. As a result of his inquiries, Parker found Missouri's pay scale deficient. ${ }^{17} \mathrm{He}$ wrote to Middlebush, in his annual report:

Since the Texas study included all regions, and some schools not comparable to the University of Missouri, letters were sent to the universities of Illinois, Indiana, Iowa, Nebraska, Tennessee, and Wisconsin. The salaries in these institutions, as compared to the University of Missouri, are given in Table III, Appendix A. This table indicates that this library is paying salaries far below those in neighboring institutions. Excluding the University of Illinois, where salaries are at least one scale step above Missouri, the University still compares unfavorably by about $\$ 300$ per year in the lower grades and by more than $\$ 1000$ at the departmental level (grade 4 ).

Not only are individual salaries low, the total expended for salaries is also low. The same table shows the total salary budget for 1948-1949 for these institutions. The University of Missouri is the lowest of all, although in size of library and student body to be served it is far larger than the universities of Nebraska and Tennessee. Indiana, Wisconsin, and Iowa, which are comparable in size to Missouri, had salary budgets in 1948-1949, at least 50 per cent larger. ${ }^{18}$

Largely due to this salary issue, the library at MU experienced some turmoil with personnel before Parker joined the system. During the course of the 1945-1946 academic year, nearly the entire cataloging department resigned..$^{19}$ Aside from low salaries (and general migration due to the end of World War II), few other details explain the mass departure except that, according to Parker, the librarians were frustrated that the administration recognized them neither as staff nor as faculty. The consequences of the exodus, mixed with developments related to the war's end, were dire. In the following 1946-1947 academic year, postwar enrollment jumped to about 13,000 students and the book budget increased with it. The loss of the cataloging librarians strained collection development, acquisition, and processing, and the result was a serious backlog that would not be fully remedied for decades.

Parker's recollection of this time included the general attitudes about the library among those in MU's administration. There seemed a consensus that a library's primary purpose was simply to acquire and process books. The administration gave little consideration, for instance, to the complexities related to building and managing a collection or to serving the patrons. For example, soon after Parker arrived and started hiring librarians, faculty from the business and public affairs schools and later, as word spread, the economics department communicated with one of the university librarians to request that she become the primary person responsible for selecting books for their subjects. Faculty from these departments would submit to the librarian their lists of the materials needed, but the librarian herself would be the primary collector. This marked the beginning of liaison and subject work at MU, which was a significant change in the role of the campus librarians, as it was in other academic libraries at the time. ${ }^{20}$ According to Parker, however, some among the administration strongly protested the development.

The attitudes among those in the administration persisted for years and extended to the state's elected officials. In the early 1950s, Missouri Governor Philip Donnelly (1945-1949 and 1953-1957) and the legislature passed a budget that drastically reduced 
funding for higher education. MU President Middlebush, according to Parker, required the library to shoulder much of the burden of the cuts, and Parker titled his 1953-1954 annual report "A Year in Crisis." ${ }^{21}$ The report, which begins with a section titled "Decline of Library Position," continued to document how the library unfavorably compared to libraries at other institutions. For instance, the head of the cataloging department resigned that year, and Parker noted that although she would have earned $\$ 4,200$ the next year, people with less experience in the job search were asking for a salary of $\$ 5,400$, further indicating that MU significantly underpaid its librarians.

The library did not begin to see financial relief until University President Elmer Ellis succeeded Middlebush in 1955, but since the state budget was biennial, Ellis could not make significant alterations until the 1957-1958 academic year. Still, Ellis was friendly to the library. ${ }^{22}$ Eventually, with the help of a stronger economy, higher enrollment, and more favorable (to higher education) state politicians, in 1957 Governor James T. Blair (1957-1961) and the legislature increased MU's funding. Ellis responded by dramatically increasing the library's budget, which rose from $\$ 150,000$ to $\$ 350,000$ per year (in 1957 dollars) for the 1957-1959 biennial budget calendar.

The budget increase allowed Parker to acquire and install an IBM Cardatype Type 858 punched-card system to help with acquisitions, ${ }^{23}$ a rare kind of purchase for libraries at the time. However, although ten years had passed since the cataloging librarians departed, staffing was just beginning to stabilize. ${ }^{24}$ In his 1958-1959 annual report, Parker's table of personnel of departmental and branch librarians illustrated how young the staff were in terms of years of employment. Out of 78 total staff, only 7 had been at the library in or before 1947 and about 85 percent started work in or after 1955.

Processing the increased acquisitions, even with the IBM Cardatype, was a challenge. No more than two-thirds of the annually acquired volumes were cataloged. ${ }^{25}$ By 1959 , there were 46,479 items that remained uncataloged, ${ }^{26}$ and by 1960 , the backlog had grown to 57,008 volumes. ${ }^{27}$ Additionally, although the library used the Dewey Decimal Classification (DDC) system, it had not been strictly followed since the 14th edition (by this time the 16th edition was available), and about 25 percent of the collection used a modified, localized adaptation of the DDC. The inconsistent use of a standardized classification system had impeded progress. However, Parker and his librarians took advantage of the backlog to switch to the Library of Congress Classification (LCC) system. It was also during this two-year period that Parker began experimenting with computers (and not punched-card systems alone), and his 1962-1963 annual report is the first report with a section dedicated to the automation of library records. ${ }^{28}$

In 1963, twenty-seven years after Parker first used a punched-card machine at the University of Texas, technological developments and economies of scale allowed automation to gain momentum across the nation. ${ }^{29}$ The Library of Congress issued its first report on automation titled "Automation and the Library of Congress," 30 and the American Library Association (ALA) formed the Association of Research Committees on Automation. This marked the beginning of an active national movement toward the automation and computerization of libraries.

In June 1964, the ALA Pre-Conference Institute on Introduction to Data Processing took place at the University of Missouri. ${ }^{31}$ Led by Parker, the focus of the conference was to introduce and familiarize librarians with data-processing equipment and procedures. 
Parker keynoted with a speech titled "The Machine and the Librarian." ${ }^{32}$ He touched on the angst, prevalent during the time, that machines would control or render humankind irrelevant or subservient. ${ }^{33}$ Parker wrote:

But there is a danger that the machine will become temporarily the nominal master. Machines have limitations in their capabilities, and the people who operate them tend to let the machine dictate what and how things are done. When this happens, it is a defeat for human ingenuity. Of course we must work within the confines of existing technology, but it need not be a straight jacket. ${ }^{34}$

Others were simply hesitant about steamrolling through the changes. Barbara Evans Markuson, a librarian at the Library of Congress and a colleague of and collaborator with Henriette Avram, made note of the trepidation in her report on Project MARC (Machine Readable Cataloging). She wrote, “To many, our progress has been much too slow; others are comforted by the thought that the national library is not rushing pell mell into automation." ${ }^{35}$ At the Proceedings of the 1963 Clinic on Library Automation of Data Processing at the University of Illinois, Ralph E. McCoy, director of libraries at Southern Illinois University, responded to Parker's presentation on automation developments at MU by writing, "Today there is a rush to climb the bandwagon on automation, and our library has recently joined the parade." ${ }^{36}$ Thus, while Parker delivered his keynote to those interested in applying the new technologies, he was inclined to couch his speech within a rhetoric of persuasion. This effort to sell his ideas meant a focus on how automation could augment the intellectual activity of librarianship—supplementing what he called "the effectiveness of the professional." ${ }^{37}$ Furthermore, automation could give librarians a reprieve from the mundane and repetitive tasks- "the elimination of clerical aspects of professional positions" 38 - that often dominated the practice and which tended to shape the perception that libraries were barely more than warehouses.

Half a year after the pre-conference, on December 1, 1964, Parker installed an IBM 357 computer for circulation. As a result, loans increased by more than 20,000 items. ${ }^{39}$ Data input into the machine was accomplished either by punched card or by typewriter. Parker, in his annual librarian report, wrote, "To the delight of the patrons it requires only four seconds to check out materials if they have the new ID card and the book has the book card." 40 To log the event, Parker documented the names of the first student and the first faculty member to use this system. A year and a half later, in May 1966, the library added an IBM 1440 computer to store the records of books on loan. The use of that computer motivated Parker to write in his annual report that "for the Circulation Department and for the Library generally this has been the year of the computer." ${ }^{41}$ The library's data-processing department operated the IBM 1440, which had two disk drives and a punched-card system. With this machine, card catalog production increased nearly 25 percent year after year and lending increased by 20 percent.

In May 1965, the MU Library joined Henriette Avram's Project MARC, along with fifteen other academic, public, and national libraries. ${ }^{42}$ Parker briefly referred to this project in his annual report: "Mr. Yeates, Head of Data Processing, was placed on temporary assignment to the MARC project, an experimental project to utilize machine readable catalog copy prepared by the Library of Congress." 43 Two months later, the Acquisitions Division changed its name to the Technical Services Division. This involved the creation of the Department of Data Processing, which became part of Technical Services. ${ }^{44}$ 
In September, a committee within the Ohio College Association (OCA) recruited Parker and Kilgour, who was then at Yale University Library, as consultants. OCA had spent fifteen years debating how to realize its goal for a bibliographic center that would help Ohio colleges and universities share resources and curtail expenses ${ }^{45}$ by maintaining bibliographies and catalogs, and possibly functioning as an interlibrary lending agency. ${ }^{46}$ In the process, they had received two commercial bids for constructing the center and asked Parker and Kilgour to judge the merits of these bids. ${ }^{47}$ Parker and Kilgour rejected both as well as the entire notion of a bibliographic center and instead proposed "the establishment of a cooperative, computerized, regional network in which most, if not all, Ohio college libraries will participate." ${ }^{48}$ The committee requested a formal report for Parker and Kilgour's "computerized, online, shared cataloging system," 49 which they submitted in December. This report, titled "Report to the Committee of the Ohio College Association," marked the beginning of OCLC, with Kilgour later serving as its first director.

Kilgour is Parker's most notable and esteemed advocate. Nearly five decades after Kilgour published the details of his own initial automation efforts, he wrote a reflection on the prehistory of OCLC. His described two events where "Ralph Parker played a major role in shaping" his professional career. ${ }^{50}$ The first event was Parker's 1936 Library Journal article, which inspired Kilgour to replicate Parker's University of Texas efforts at Harvard University in 1939..$^{51}$ The second event, nearly thirty years later in 1965, involved Parker and Kilgour writing the OCA report. The Parker-Kilgour-OCA consultation was the first time the two librarians met in person, and in Kilgour's reflection on this, he expressed surprise that it took decades for the two to meet. He remarked, "For a second time, Ralph Parker played a major role in shaping my professional career." 52

\section{Automation, Its Conflicts, and the Collective Will}

It required a herculean effort to automate libraries. ${ }^{53}$ Various library leaders realized that for library automation to succeed and make sense, economically or otherwise, the task required the coordinated efforts of many

It required a herculean effort to automate libraries. librarians from many libraries. ${ }^{54}$ Achieving this convergence was a great difficulty. Parker noted, in a 1966 lecture given at Oxford University, that the difficulty was often just a way of thinking or a mode of doing - that "librarians seldom take a

systems approach to mechanization; their interests are directed to the solution of specific problems." 55

For Parker, the difficulty was also attributable to the relationship between "man and machine," which was an anxious one in the twentieth century. ${ }^{56}$ That is, while today people seem concerned about technologically induced information overload, in the previous century people seemed concerned about machines in general, under the view that they were an existential threat rather than a threat to our well-being. ${ }^{57}$ The tension was readily apparent in librarianship ${ }^{58}$ and motivated Jesse Shera to scold librarians and respond to the general angst associated with these machines. He wrote: 
There is a computer in your future, there is no doubt about that, and whether one regards it as the monster of a Frankenstein or the harbinger of a new industrial revolution will not change the course of events. Men will continue to experiment with machines for the performance of intellectual tasks whether librarians approve or not, just as men continued to extend their physical prowess with the aid of machines despite the opposition of Luddites. ${ }^{59}$

In light of those who praised the machine, those who dreaded what it portended, and those like Shera, who sought to present a reality check, it is important to note that a key insight found by reviewing the documents left by Parker and his administration is that technology simply played an instrumental role in his vision of a professional library. That is, there were numerous administrative reasons to pursue developing efficient methods for dealing with growing collections and rising circulation, and it was in this sense that Jesse Shera described Parker's automation efforts as "library housekeeping," posed to theoretical or empirical research with automation or information retrieval. ${ }^{61}$ However, as a library director Parker also used technology as a means to an end, where the end meant a better profession and a better library. It may have been housekeeping, but there was an important, professional reason for it.

In the broad sense, if there was a joint will to connect libraries together, then the implications that the ability to act jointly had on the development of librarianship as a profession are what defines the field as a profession. It is true that the many changes required to automate libraries seemed inevitable given various developments, but what is particularly nontrivial about this period was the personal and collective determination to see through this transformation over the long run. ${ }^{62}$ The collective actions of these librarians are thus significant and historically fascinating, especially given their constraints, because automation only made sense if it was collectively pursued. ${ }^{63}$ The needs of automation made modern librarianship, in fact, modern.

Arthur T. Hamlin refers to the 1930s as a "'mirabilis' for research librarians" because "the period saw the birth of three influential professional journals [and] with these came an extraordinary flood of publication on professional problems where previously there had been only a mere trickle through the Library Journal." ${ }^{64}$ Other events, such as the 1936 founding of the American Documentation Institute (ADI), ${ }^{65}$ a response to technological innovations and advances in microphotography and to the increased need to search for and retrieve relevant scholarly communication, ${ }^{66}$ also contributed to this "miracle" decade. These events, framed too by Parker's initial work with punched cards $^{67}$ and Kilgour's follow-up work in $1939,{ }^{68}$ seem to signal a kind of classical age of librarianship that lasted through the late 1960s. ${ }^{69}$ Such an age has less to do with some idealized past and more with how that period set the boundaries within which academic librarians function today.

In 1967, Parker published a short piece titled "The Small Library Faces the Future." 70 The piece prognosticates the end of the small library as a result of automation and computerization. On a too literal reading, the piece appears myopic given that small libraries are still common, but on a closer reading, it was a solid interpretation of things to come. As Parker's and others' visions of the library developed throughout their careers, the vision of the library went beyond its physical boundaries, beyond the library building, to be redefined in light of automated and integrated library systems. 
This was an important step for the field. It meant that even the smallest physical library would no longer exist as an island-that it had more to offer than what resided inside its walls. In 1967, Parker wrote:

\begin{abstract}
At least another decade will be required before individual libraries can be partners in a broad, comprehensive, educational communications network by means of typewriter keyboards and television screens. But the small library can look forward to the day when bibliographic citations are instantaneously available and will appear on a television screen and, perhaps, even the time when hard copy excerpts from books and periodicals can be obtained via this network within a matter of minutes. ${ }^{71}$
\end{abstract}

\title{
Conclusion
}

The middle span of the twentieth century witnessed some of the most tremendous changes for libraries and librarianship. For librarians, the century began with not only

\section{The vision of the library went beyond its physical boundaries, beyond the library building, to be redefined in light of auto- mated and integrated library systems.}

having weak jurisdiction over their domain and little control over their collections, but it also began at a time when few technologies, and no automated ones, meant it was burdensome and prone to error to manage a collection, loan a book, or maintain the kind of collective will and action needed to operate as a profession. While academic libraries still face many challenges, many of these challenges are consistently professional grade; that is, they more often than not involve sophisticated technological, social, and ethical issues that by their nature require a professional response.

Parker's use of technology is an example of an important heuristic for librarianship or for any profession. The importance of evaluating and assessing any technology, or any substantive addition to the library, not only by how well it serves the patron but also by how well it serves librarians and the profession, has the potential to benefit not just the profession but also those the profession serves. The heuristic does not entail using technology for its own sake, but using it critically. Consequently, if the heuristic's application means abandoning certain technologies, focusing less on providing information, and providing more community, contemplative spaces, entertainment, or places for creating and evaluating knowledge and art, then perhaps that may be its best application. Whatever the outcome, this ability to adapt and reinvent, under great duress, is an aspect of what Andrew Abbott meant by being able to negotiate the "link of jurisdiction" due to "the context of larger social and cultural forces" that affect our work. ${ }^{72}$

\section{Acknowledgements}

The author thanks the peer reviewers for their comments, Kris Anstine and Gary Cox at University of Missouri Archives for their guidance, and Dr. Thomas R. Kochtanek, whose personal stories of Ralph H. Parker inspired learning more about the person. A 
very early draft of this paper was presented to the 2011 Historical Perspectives Special Interest Group (SIG) at the annual conference of the Association for Library and Information Science Education (ALISE) in San Diego.

C. Sean Burns is an assistant professor in the School of Library and Information Science at the University of Kentucky in Lexington; he may be reached by e-mail at: sean.burns@uky.edu.

\section{Notes}

1. There are two excellent historical accounts of the beginnings of academic libraries and librarians. See Arthur T. Hamlin, The University Library in the United States: Its Origins and Developments (Philadelphia: University of Pennsylvania Press, 1981) and Orvin L. Shiflett, Origins of Academic Librarianship (Norwood, NJ: Ablex, 1981). See Derek J. de Solla Price's work Little Science, Big Science ... and Beyond (New York: Columbia University Press, 1963) for an expansion on ideas related to scholarship and research. Price's account of the development of modern-day science and the scientist illustrates the growth of science in the twentieth century.

2. Eldred Smith, The Librarian, the Scholar, and the Future of the Research Library (New York: Greenwood Press, 1990), 39-40.

3. Andrew Abbott, "Professionalism and the Future of Librarianship," Library Trends 46, 3 (1998): 430-43.

4. Parker, "The Punched Card Method in Circulation Work," Library Journal 61 (December 1936): 903-5.

5. Ralph H. Parker and Frederick G. Kilgour, "Report to the Committee of Librarians of the Ohio College Association," in Collected Papers of Frederick G. Kilgour: OCLC Years, ed. Lois L. Yoakum (Dublin, OH: OCLC Online Computer Library, 1984), 1-7. A footnote in this edition states: "Report prepared in 1965. Reprinted from The Ohio College Association and the authors." This is the report that directly led to the founding of OCLC.

6. Parker, "The Punched Card Method in Circulation Work," 905.

7. Since a great deal of material for this study relies on Parker's annual librarian reports, a brief description of one of the reports is helpful. The "Annual Report, University of Missouri Library, 1948-1949, Vol. I" contains chapters titled "Report of the Librarian," the "Reports of Department Heads," and the "Reports of Branch Librarians." The "Report of the Librarian" begins with a letter from Ralph H. Parker to the president of the university, at this time Dr. Frederick A. Middlebush. The letter summarizes the report's key points, and most specifically, it outlines arguments about why the library did well or did not do well in the year. The letter ends with a short paragraph in praise of the "devotion of the staff."

Following the letter is a table of contents and then the university librarian's annual report, which begins with a twelve-page document with sections titled Personnel, Use of the Library, Processing of Materials, Branch Libraries, Library Committee, Microfilm Service, and Recommendations.

An appendix of tables comes next. There are twenty-three tables in the first appendix (Appendix A), and they provide data on a range of topics, including staff, circulation, interlibrary loans, financial statements, and so forth. Appendix B contains a five-page list of individual donors for the year, and this is followed by an additional two-page list of individual faculty donors. Appendix $\mathrm{C}$ contains three tables. The first table is a more than five-page list of all new periodical subscriptions for the year. The second table is a less than one-page list of newspapers received on microfilm. The third table is a two-page list with the caption "A Few Unusual Purchases," many of which appear to be items for special collections, such as books published in the seventeenth, eighteenth, and nineteenth centuries. 
After the university librarian's report comes the report from the Acquisitions Department. Investigation of this departmental report and the others shows that the university librarian's report is a summary of the departmental and branch library reports. For example, the Acquisition Department's report includes a section describing the library's participation in the Farmington Plan, a national program of cooperation among research libraries, which includes about three pages of textual description and close to a two-and-a-half-page table of the books received as part of the plan. The university librarian's report summarizes the Acquisition Department's section on the Farmington Plan in two paragraphs.

Just as the university librarian begins his report with a summary of the library as a whole, the beginning of most departmental and branch library reports includes a summary of that department's or branch's activities for the year. These summaries are written in a very personal, first-person narrative style. The annual reports for this year and the following years remain fairly consistent in format, scope, and topical matters. On May 11, 1949, University of Missouri President Middlebush sent a letter to the deans and administrative officers asking for a more uniform report. This letter contains an outline of the minimum requested information by category (C:20/00/4, Box 1, LIBRARIES, Annual \& Departmental Reports, folder titled "Working Papers 1948-9").

8. For an earlier account of Parker's work, see this master's thesis: Mina Hoyer, "The History of Automation in the University of Missouri Library, 1947-1963" (master's thesis, Indiana University, 1965), 22.

9. For a good, brief description of the manual, preautomated method used to loan and circulate books, see the first paragraph of the following encyclopedia article: Jamshid Beheshti, "Library Automation," in Encyclopedia of Communication and Information, ed. Jorge Reina Schement (New York: Macmillan Reference USA, 2002), accessed December 26, 2012, http://go.galegroup.com/.

10. Irene Farkas-Conn writes that "the Boston Public Library used punched cards for analyzing acquisitions in 1934," but it seems no one from Boston published about their efforts and Farkas-Conn's information is based on an interview she conducted decades later. Irene S. Farkas-Conn, From Documentation to Information Science: The Beginnings and Early Development of the American Documentation Institute-American Society for Information Science (New York: Greenwood Press, 1990), 132.

11. Kenneth E. Carpenter makes the case that part of the problem with academic librarians gaining a respected status in the academy results from the organizational structure of the academy. He writes, "Hierarchical organizations have limited the role of most librarians and have been crucial to the low status of librarianship" (85). It does not help that the academy is an organization that has traditionally embodied a hierarchical structure. Kenneth E. Carpenter, “A Library Historian Looks at Librarianship," Daedalus 125, 4 (1996): 77-102.

12. Robert V. Williams, "The Use of Punched Cards in US Libraries and Documentation Centers, 1936-1965," IEEE [Institute of Electrical and Electronics Engineers] Annals of the History of Computing 24, 2 (2002): 17. For an additional account covering libraries in both the United Kingdom and the United States, see Alistair Black, "Mechanization in Libraries and Information Retrieval: Punched Cards and Microfilm Before Widespread Adoption of Computer Technology in Libraries," Library History 23 (December 2007): 291-99.

13. Judith Hopkins, "The Ohio College Library Center," Library Resources \& Technical Service 17, 3 (1973): 309.

14. According to MU Archives, "Attendance at MU, which consisted of around 5,000 enrolled students in 1938, dropped to around 1,500 by 1943. Many students and faculty entered the service or left the University to help in other areas of the war effort." "The Military and Mizzou: 1861-1946," Archives of the University of Missouri, last modified January 19, 2007, http: / / muarchives.missouri.edu/ military.html. 
15. Parker used these grade levels to classify the librarians in Tables II, III, and IV, Appendix A of the 1948-1949 "Annual Report," C:20/4/2, Box No. 4. These tables compare MU librarian salaries to librarian salaries at other institutions. The University of Texas system, one of the systems Parker used to make a comparison, had a librarian grade referred to as deputy librarian. MU did not have a similar rank.

16. This is confirmed by Benjamin Edward Powell's "Annual Report of the University Librarian, 1943." Powell was the acting university librarian and university librarian from 1937 to 1946 . According to Powell's report, the library paid a total of $\$ 46,849.44$ in salaries for the year 1941, and this total had increased to $\$ 52,875.34$ in 1942 but then dropped to $\$ 48,745.58$ in 1943. C:20/4/2, Box No. 1.

17. The letters Parker received from these other institutions are in C:20/00/4, Box 1, LIBRARIES, Annual \& Departmental Reports, folder titled "Working Papers 1948-9."

18. Parker, "University of Missouri Library, Annual Report of the University Librarian, 1948-1949." C:20/4/2, Box No. 2.

19. Benjamin E. Powell, the university librarian preceding Parker, documents the beginning of the mass resignations in "Report of the Librarian, University of Missouri Library, 1945; 1945 / 46," C:20/4/2, Box No. 1. When Powell wrote his 1945 and 1945-1946 report (a report covering a year and a half due to a change in the state's fiscal year), he listed eleven members of the staff, but four are listed as having resigned during the report's time frame. When Parker wrote his first report, which was for the 1946-1947 calendar year, he noted that five other catalogers or assistant catalogers had resigned before he accepted the position as university librarian but after Powell had departed.

20. Hamlin notes that, even up to this time, faculty still largely determined academic library collections. Arthur T. Hamlin, The University Library in the United States: Its Origins and Development (Philadelphia: University of Pennsylvania Press, 1981), 63.

21. This paragraph draws some content from the following recorded interview: Ralph $\mathrm{H}$. Parker, interview by Patricia Timberlake, 1975, "Parker: History of His Time at Ellis," Archives of the University of Missouri. An audio excerpt of the interview is available online at http: / / muarchives.missouri.edu / parkerau.html. C:22 / 4 / 1. Parker's 1953-1954 annual report provides additional details about the budget cuts and is rather scathing about the reductions. C:20/4/2, Box No. 4, "Annual Report, University of Missouri Library, 1953-1954."

22. In 1971, the MU Board of Curators honored President Elmer Ellis and officially renamed the university library as Elmer Ellis Library, last modified August 19, 2003, http: / / muarchives.missouri.edu/libraryexchr.html.

23. Parker, "Automatic Records Systems at the University of Missouri Library," College $\mathcal{E}$ Research Libraries 23, 3 (1962): 231.

24. In Parker's 1958-1959 annual report (C:20/4/2, Box No. 5), he wrote: “Turnover of professional staff was the lowest in years (only two resignations), thanks to a much improved salary scale. The quality of the staff is better than at any time in ten years," 6 .

25. Ralph H. Parker, "Development of Automatic Systems at the University of Missouri Library" with a discussion led by Ralph E. McCoy, in Proceedings of the 1963 Clinic on Library Acquisitions on Data Processing held at the Illini Union on the Urbana Campus of the University of Illinois, April 28-May 1, 1963, ed. Herbert Goldhor (Champaign, IL: Illini Bookstore, 1963), 43-61.

26. From Table X, Appendix A of Parker's 1958-1959 “Annual Report." MU Archives, C:20/4/2, Box No. 5 .

27. University of Missouri Library, "Annual Report of the University Librarian, 1959-1960," Table XI, C:20/4/2, Box No. 5.

28. University of Missouri-Columbia Library, "Annual Reports of the University Librarian, 1962-1972." University of Missouri Library, "Annual Report of the University Librarian, 1962-1963," C:20/4/1, Box No. 1. 
29. For more history, see Linda C. Smith, "From Data Processing to Knowledge Engineering: The Impact of Automation on Public Services," in Design and Evaluation of Computer/ Human Interfaces: Issues for Librarians and Information Scientists, ed. M. A. Siegel (Urbana, IL: Graduate School of Library and Information Science, 1988), 3-25, http: / / hdl.handle. net/2142/1250.

30. Library Quarterly published a tripartite response to this report that involved Robert $\mathrm{M}$. Hayes, information scientist, Ralph H. Parker, university librarian, and Gilbert W. King, chairman of the Survey Team for the Library of Congress. See "Automation and the Library of Congress: Three Views," Library Quarterly 34, 3 (July 1964): 229-39.

31. MU Archives. C:20/1/1, Box 1, Libraries, General Correspondence.

32. The keynote was published as: Ralph H. Parker, "The Machine and the Librarian," Library Resources \& Technical Services 9, 1 (1965): 100-103.

33. The mid-twentieth century is rife with literature about the societal anxiety with machines. Norbert Wiener's "Some Moral and Technical Consequences of Automation" is an excellent summary of what some believed to be the worst-case scenarios of a future of automation. Science 131, 3410 (May 6, 1960), 1355-58. Also see Sungook Hong, "Man and Machine in the 1960s," Techné 7, 3 (2004): 49-77, http:/ / scholar.lib.vt.edu/ ejournals/SPT/v7n3/hong.html.

34. Parker, "The Machine and the Librarian," 102.

35. Barbara Evans Markuson, "The Library of Congress Automation Program: A Progress Report to the Stockholders," ALA Bulletin (June 1967): 648.

36. Parker, "Development of Automatic Systems at the University of Missouri Library" with a discussion led by Ralph E. McCoy, 55, http: / / hdl.handle.net/2142/742.

37. Parker, "The Machine and the Librarian," 102.

38. Ralph H. Parker and Agnes L. Reagan, "Ports of Entry to Librarianship [with Discussion]," Library Quarterly 31, 4 (1961): 344.

39. University of Missouri Library, "Circulation Department, Annual Report, 1964-1965." C:20/00/4, Box 2.

40. Parker, "Report of the Librarian, University of Missouri, Annual Report of the Librarian, 1964-1965." C:20/4/2, Box No. 1, Vol. 1962/72.

41. Parker, "Report of the Librarian, University of Missouri, Annual Report of the Librarian, 1965-1966." C:20/4/2, Box No. 1, Vol. 1962/72.

42. Barbara Evans Markuson, "The Library of Congress Automation Program." For a full and technical description of Project MARC at the time, see Henriette D. Avram and Barbara Evans Markuson, "Library Automation and Project MARC: An Experiment in the Distribution of Machine-Readable Cataloging Data, in The Brasenose Conference on the Automation of Libraries: Proceedings of the Anglo-American Conference on the Mechanization of Library Services Held at Oxford Under the Chairmanship of Sir Frank Francis and Sponsored by the Old Dominion Foundation of New York, ed. John Harrison and Peter Laslett (June 30- July 3, 1966): 97-127.

43. Parker, "Report of the Librarian, University of Missouri, Annual Report of the Librarian, 1966-1967." C:20/4/2, Box No. 1, Vol. 1962/72.

44. Parker, "Report of the Librarian, University of Missouri, Annual Report of the Librarian, 1965-1966." C:20/4/2, Box No. 1, Vol. 1962/72.

45. Kilgour, "Historical Note: A Personalized Prehistory of OCLC," Journal of the American Society for Information Science 38, 5 (1987): 381-84.

46. This facility would have been a bibliographic center (or centre) as defined in Leonard Montague Harrod, The Librarians' Glossary of Terms Used in Librarianship and the Book Crafts and Reference Book (New York: Seminar Series, 1971), 77.

47. Judith Hopkins, “The Ohio College Library Center," Library Resources E Technical Service 17, 3 (1973): 308-19.

48. Parker and Kilgour, "Report to the Committee of Librarians of the Ohio College Association."

49. Kilgour, “Historical Note: A Personalized Prehistory of OCLC," 383. 
50. Ibid.

51. Kilgour, "A New Punched Card for Circulation Records," in Collected Papers of Frederick G. Kilgour: Early Years, ed. Lois L. Yoakum (Dublin, OH: OCLC Online Computer Library, 1984), 7-10. Reprinted from Library Journal 64, 4 (February 15, 1939), 131-33.

52. Ibid.

53. The domestication of new and disruptive technologies, such as the telephone and the automobile, is a well-researched topic and is relevant to the automation of libraries. Mika Pantzar, "Domestication of Everyday Life Technology: Dynamic Views on the Social Histories of Artifacts," Design Issues 13 (Autumn 1997): 52-65.

54. See Ralph H. Parker, "Book Catalogs," Library Resources E Technical Services 8 (Fall 1964): 344-48 for an example of a regional cooperative effort. Also, the augmented value of automation came not from localized instances of task automation but from the integration through the network of such localized instances with other entities doing similar work. Such collective action had an economic value as a result of increased adoption. For a brief overview of what such "network effects" are see http: / / oz.stern.nyu.edu/io/network. html.

55. Ralph H. Parker, "Library Records in a Total System," in The Brasenose Conference on the Automation of Libraries, 33. Many historically prominent library and information scientists attended this conference, including Henriette D. Avram, Barbara Evans Markuson, and Frederick G. Kilgour. The conference took place a little more than six months after Parker and Kilgour submitted their Ohio College Association report recommending what later became OCLC.

56. For a worthwhile exploration of technological faith and associated tensions in the context of librarianship, see Hal B. Grossman, "A Comparison of the Progressive Era and the Depression Years: Societal Influences on Predictions of the Future of the Library, 1895-1940," Libraries \& the Cultural Record 46, 1 (2011): 102-8. However, despite Parker's enthusiasm for automating libraries, his writings seem to lack any hint of a Progressive era outlook. Rather, in addition to his interest in librarians, his outlook seems influenced by a kind of pragmatism.

57. For a broader, cultural view about societal anxiety with machines, see Norbert Wiener's "Some Moral and Technical Consequences of Automation." Also see Sungook Hong, "Man and Machine in the 1960s."

58. See Stephen R. Salmon, "Information Science and Automation: The Newest Division," ALA Bulletin 67 (June 1967): 637-42. Salmon provides an account of the formation of the ALA Information Science and Automation Division (ISAD), now known as the Library and Information Technology Association (LITA). His account details the arguments made against the division's creation, and this includes detailing the claims made by some that the new technologies were not important enough to call for ALA division status.

59. Jesse H. Shera, "What Is Past Is Prologue: Beyond 1984," ALA Bulletin 61 (January 1967): $41-42$.

60. Shera, "What Is Past Is Prologue," 37. Shera's description of Parker's work as housekeeping does not seem condescending, just specific.

61. Automation opened the door for information retrieval research studies, and Parker did contribute theoretical studies, especially after his library administrative responsibilities ended. For example, see Ralph H. Parker, "Bibliometric Models for Management of an Information Store. I. Differential Utility Among Items," Journal of the American Society for Information Science 33 (May 1982): 124-28; Parker, "Bibliometric Models for Management of an Information Store. II. Use as a Function of Age of Material," Journal of the American Society for Information Science 33 (May 1982): 129-33; and Parker, "Bibliometric Models for Management of an Information Store. III. Developing an Empirical Model," Journal of the American Society for Information Science 33 (May 1982): 134-38.

62. Parker pursued his automation project for more than thirty years before librarians really began to automate. Kilgour displayed the same lengthy persistence. When the Library of 
Congress began to plan for automation, according to Gilbert W. King, they "sought a plan to provide a blueprint for its actions during the next 5 to 10 years." See Robert M. Hayes, Ralph H. Parker, and Gilbert W. King, "Automation and the Library of Congress," 235.

63. This is supported by Markuson: "The need for financial and human resources will be ever more evident as librarians acquire and use complex machinery such as computers, on-line consoles, and photocomposers, and as they begin to convert huge data files. Cooperation among libraries in both the planning and execution of automation programs is mandatory." Markuson, "The Library of Congress Automation Program," 655.

64. The three important journals that were founded in the 1930s are the Library Quarterly (1931), The Journal of Documentary Reproduction (1938), and College E Research Libraries (1939). Furthermore, this is the decade that saw the founding of the Association of Research Libraries (1932) and the Association of College and Reference Libraries (1938). Hamlin, The University Library in the United States, 60.

65. “The American Documentation Institute," Science 85, 2210 (May 7, 1937): 447. Retrieved from http:/ / www.jstor.org/stable/1663053.

66. Farkas-Conn, From Documentation to Information Science.

67. Parker, "The Punched Card Method in Circulation Work."

68. Kilgour, "A New Punched Card for Circulation Records."

69. Automation was actively pursued in the intervening years but only in piecemeal. It was not until the 1960s, with the Library of Congress Report on Automation, Project MARC, the founding of OCLC, the forming of the ALA Information Science and Automation Division (later to become LITA, the Library and Information Technology Association), and other events that a collective momentum began building. However, it should be noted that the pursuit of library automation, while largely slow during the 1940s and 50s, was not abandoned during these two decades. Two seminal works on punched-card systems were published in 1952: Howard F. McGraw, Marginal Punched Cards in College and Research Libraries (Washington, DC: Scarecrow Press, 1952); and Ralph Halsted Parker, Library Applications of Punched Cards (Chicago: ALA, 1952).

70. Ralph H. Parker, "The Small Library Faces the Future," ALA Bulletin (June 1967), 669-71.

71. Ibid., 671 .

72. Abbott, "Professionalism and the Future of Librarianship," 435. 